РОЗСОХА О. В. , доцент, канд. техн. наук, БЕРЕСТОВ І. В., доцент, канд. техн. наук,

ШАПОВАЛ Г. В., доцент, канд. техн. наук (Український державний університет залізничного транспорту)

\title{
Технологія моніторингу рівня професійної підготовки персоналу господарства перевезень залізничного транспорту
}

Рівень професійної підготовки персоналу господарства перевезень залізничного транспорту має велике значення в проведенні профілактичної роботи з забезпечення безпеки руху поӥздів.

У статті запропоновано метод визначення рівня професійної підготовки персоналу. Цей метод полягає у визначенні показників професійної підготовки персоналу та порівнянні їх з граничними значеннями. В основу математичного апарату методу покладено теорію нечітких множин.

У статті також запропоновано спрощену процедуру визначення рівня оперативної підготовки працівників господарства перевезень при діях у нестандартних ситуаціях на прикладі операторів сортувальної гірки.

Ключові слова: рівень професійної підготовки, навчання персоналу, безпека руху поӥздів, залізничний транспорт.

\section{Вступ}

Європейське залізничне агентство разом 3 Європейською комісією проводять широку програму для відкритого i конкурентоспроможного ринку залізничних перевезень i прагнуть при цьому покращити рівень безпеки. Реалізація Постанови Свропейського Союзу (СС) 402/2013 (Імплементаційний Регламент Європейської Комісії про загальний метод безпеки для виявлення та оцінки ризиків (CSM RA) і відміну Регламенту СC 352/2009) i документа [1] (Загальна безпека. Метод оцінки ризику та експертиза) надає змогу гармонізувати процеси оцінки ризиків серед країн-членів ЄС. Процеси, що відбуваються в одній державі ЄС, отримують взаємне визнання в інших країнах європейського простору.

Один 3 перших кроків руху залізничного транспорту України в європейському напрямі відбувся 1 грудня 2015 року, коли свою діяльність розпочала компанія Публічне акціонерне товариство «Українська залізниця». Важливим принципом функціонування залізничного транспорту в Україні є безпечність.

Теперішні зміни в галузі залізничного транспорту України потребують впровадження нових підходів у забезпеченні безпеки руху. Безпека руху на залізничному транспорті - це стан процесу (системи) руху залізничного рухомого складу, самого залізничного рухомого складу та об'єктів залізничної інфраструктури під час їх експлуатації, при якому ризик виникнення залізничних транспортних подій i їхніх наслідків не перевищує гранично допустимого рівня, а також забезпечується захист життя і здоров'я громадян, навколишнього природного середовища, майна фізичних чи юридичних осіб від наслідків таких подій.

(C) О. В. Розсоха, І. В. Берестов, Г. В. Шаповал, 2017
Нормальне становище 3 забезпеченням безпеки руху залежить від працівників, безпосередньо пов'язаних 3 рухом поїздів і маневровою роботою, тобто від змінних працівників: поїзних диспетчерів, чергових по станції, операторів при чергових по станції, чергових по парках, маневрових диспетчерів, операторів постів централізації, сигналістів, чергових стрілочних постів, чергових по гірці, операторів гірки, складачів поїздів, головних кондукторів, регулювальників швидкості руху вагонів, операторів СТЦ, поїзних диспетчерів та інших працівників господарства перевезень. При здійсненні заходів 3 дотримання необхідного рівня безпеки руху профілактична робота серед персоналу займає важливе місце. Всі заходи профілактичної роботи мають забезпечити високий рівень технологічної дисципліни цих працівників, суворе виконання ними вимог нормативних актів та інструкцій, які в сукупності складають правила безпеки руху.

Українські залізниці повинні поступово переходити 3 нормативного (заснованого на покараннях за відхилення від діючих норм) підходу до безпеки, який переважає в останні десятиліття, на креативний, коли невід'ємним елементом корпоративної культури $\epsilon$ навчання, відкритість i презумпція невинності, а кожна подія розглядається як невдача організації, а не помилка окремого працівника на завершальному етапі ланцюга.

Профілактична робота повинна базуватись на основі комплексного аналізу іiі інфраструктури та якості виконання технологічних операцій причетними працівниками за технологічною схемою, яку наведено на рис. 1. 


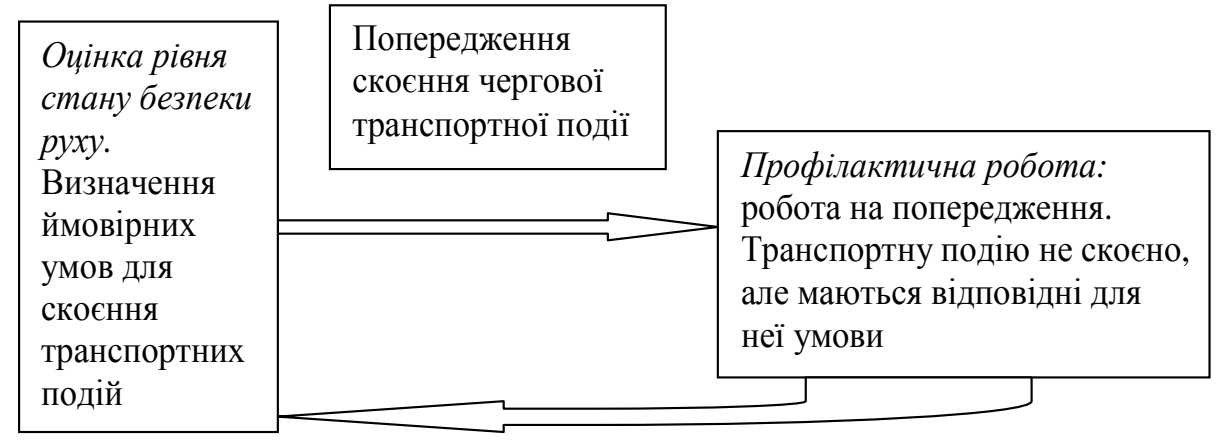

Рис. 1. Схема організації профілактичної роботи на залізницях

\begin{abstract}
Постановка проблеми
Важливим напрямом у здійсненні заходів 3 підвищення рівня безпеки руху $\epsilon$ профілактична робота, яка має безліч аспектів, але переслідує одну мету: повністю виключити або звести до мінімуму порушення безпеки в поїзній і маневровій роботі, а також травматичні випадки. Рівень професійної підготовки персоналу господарства перевезень залізничного транспорту має велике значення в проведенні профілактичної роботи 3 забезпечення безпеки руху поїздів.
\end{abstract}

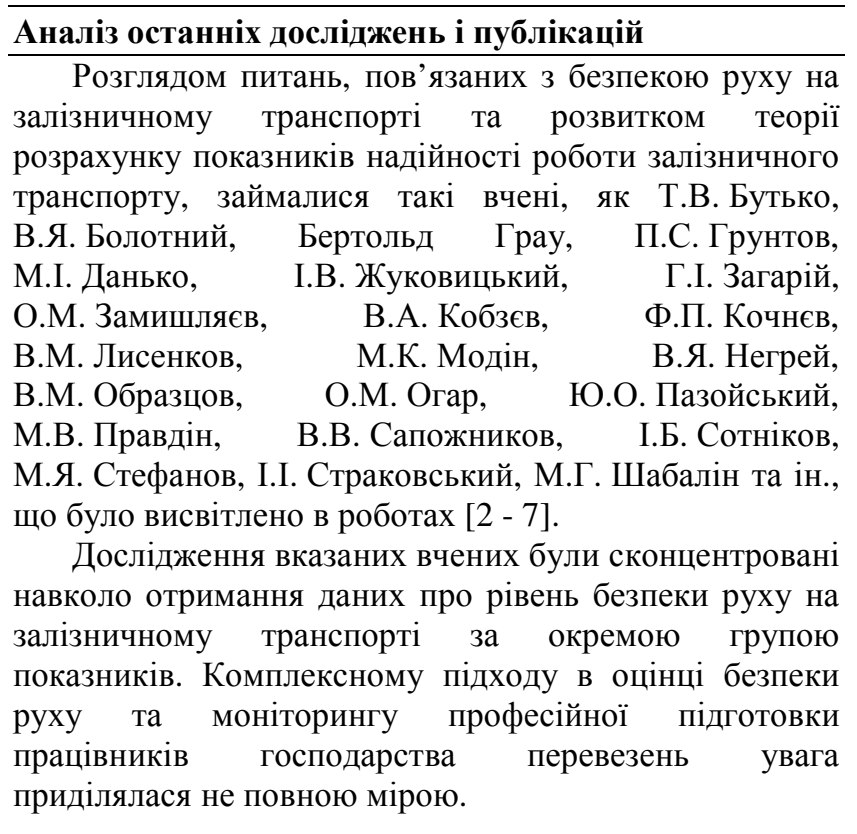

\footnotetext{
Визначення мети та задачі дослідження

Метою даних досліджень $є$ визначення способів підвищення якості перевізного процесу при удосконаленні системи управління безпекою руху поїздів. Одним із відповідних заходів $є$ розроблення технології моніторингу рівня професійної підготовки персоналу господарства перевезень залізничного транспорту.
}

\section{Основна частина дослідження}

Під безперервним моніторингом стану безпеки руху поїздів слід розуміти активний контроль за діяльністю залізничної галузі 3 боку компетентних органів регулювання 3 метою виконання вимог забезпечення безпеки. Структуру безперервного моніторингу стану безпеки руху поїздів можна подати у вигляді схеми на рис. 2.

При впровадженні нових технологій організації руху поїздів підготовка персоналу має велике значення. У зв'язку з цим підвищення кваліфікації персоналу пропонується розглядати як елемент механізму безперервного моніторингу професійної підготовки спеціалістів (табл. 1).

Джерелом інформації щодо професійних помилок залізничного персоналу можуть бути результати діяльності експлуатаційного підприємства і статистичні дані (якщо вони цілком відповідають дійсності) про ризик залізничних транспортних подій 3 вини людського фактора.

Вибір місця проходження перепідготовки може здійснюватися на підставі досвіду надання освітніх послуг як існуючих, так і новостворених навчальних центрів.

Для реалізації етапу «Ідентифікація рівня професійних якостей» розроблена матриця професіоналізму (табл. 2).

Ризик виникнення помилкових дій 3 вини людського фактора може проявлятися від незначних до істотних. Тому в матриці ідентифікації рівня професіоналізму пропонується класифікація наслідків, що складається з чотирьох груп:

- відсутність істотного впливу на результати виробничого процесу;

- низький ступінь впливу;

- середній ступінь впливу;

- сильний вплив на результати виробничого процесу. 


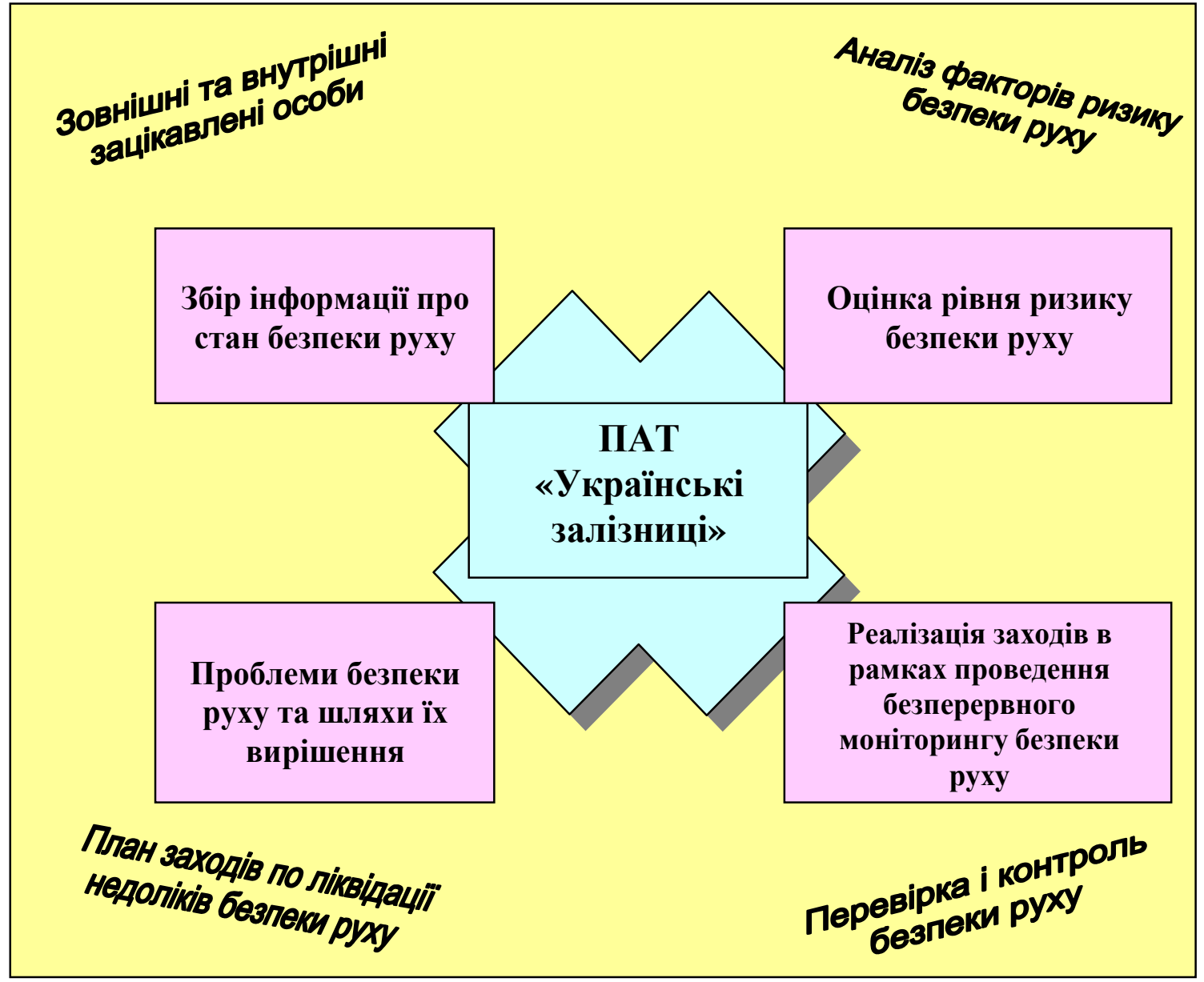

Рис. 2. Структура безперервного моніторингу стану безпеки руху поїздів

Механізм безперервного моніторингу професійної підготовки спеціалістів

\begin{tabular}{|c|c|c|}
\hline Етап & Вид контролю & Форма представлення \\
\hline $\begin{array}{l}\text { ЕТАП } 1 \\
\text { ІДЕНТИФІКАЦІЯ РІВНЯ } \\
\text { ПІДГОТОВЛЕНОСТІ }\end{array}$ & $\begin{array}{l}\text { 1) ідентифікація недоліків діяльності та } \\
\text { ризику наслідків; } \\
\text { 2) аналіз професійних помилок; } \\
\text { 3) складання переліку додаткових заходів } \\
\text { щодо скорочення помилок }\end{array}$ & $\begin{array}{l}\text { Встановлюється відповідність } \\
\text { конкретного фахівця займаній } \\
\text { посаді }\end{array}$ \\
\hline $\begin{array}{l}\text { ЕТАП } 2 \\
\text { ПЕРЕПІДГОТОВКА, } \\
\text { ПІДВИЩЕННЯ КВАЛІФІКАЦІЇ }\end{array}$ & $\begin{array}{l}\text { 1) оцінка організаційних та економічних } \\
\text { можливостей проведення перепідготовки; } \\
\text { 2) ухвалення рішення про місце } \\
\text { проходження перепідготовки; } \\
\text { 3) перелік нових повноважень і } \\
\text { відповідальності }\end{array}$ & $\begin{array}{l}\text { Реалізація заходів шодо } \\
\text { підвищення професіоналізму і } \\
\text { розвитку додаткових навичок і } \\
\text { умінь }\end{array}$ \\
\hline $\begin{array}{l}\text { ЕТАП } 3 \\
\text { КОНТРОЛЬ РЕЗУЛЬТАТІВ }\end{array}$ & $\begin{array}{l}\text { 1) виявлення недоліків підготовки та } \\
\text { перепідготовки; } \\
\text { 2) коригування планів перепідготовки; } \\
\text { 3) контроль і аналіз результатів } \\
\text { перепідготовки }\end{array}$ & $\begin{array}{lrr}\text { Формування } & \text { звітів про } & \text { стан } \\
\text { кадрового } & \text { потенціалу } & \text { для } \\
\text { залізниці } & & \end{array}$ \\
\hline
\end{tabular}




\section{Ідентифікація рівня професійної підготовки}

\begin{tabular}{|c|c|c|}
\hline $\begin{array}{c}\text { Загроза виникнення помилкових } \\
\text { дій }\end{array}$ & $\begin{array}{c}\text { Наслідки (наявність суттєвого } \\
\text { ступеня впливу на результати } \\
\text { виробничого процесу) }\end{array}$ & $\begin{array}{c}\text { Періодичність виникнення подій у } \\
\text { звітному періоді }\end{array}$ \\
\hline$\ll \mathrm{O} »$ & Відсутність впливу & $0-2$ \\
\hline$\ll \mathrm{H}$ & Низький вплив & $3-11$ \\
\hline$\ll \mathrm{C}$ & Середній вплив & $12-16$ \\
\hline$\ll \mathrm{K} »$ & Високий вплив & 17 та більше \\
\hline
\end{tabular}

Періодичність виникнення подій у звітному періоді характеризується не тільки кількістю, а й рівнем їх наслідків. Наприклад, виникнення подій у кількості від 3 до 11 за шкалою «низький ступінь впливу» не є критичним. Але, щоб уникнути ризику переходу в більш тяжкі наслідки, пропонується в кожній 3 класифікаційних груп орієнтуватися на середне значення. Таким чином, на підставі даних табл. 1, 2 можна побудувати матрицю для визначення рівня професіоналізму фахівців різних категорій господарства перевезень залізниці (табл. 3).

Практично такий підхід до оцінки рівня професіоналізму і підготовленості персоналу можна використовувати в навчальних центрах у процесі перевірки рівня теоретичних знань, у навчальнотренувальних центрах при оцінці практичних навичок з використанням технічних засобів навчання.

Матриця визначення рівня підготовленості персоналу

\begin{tabular}{|c|c|c|c|c|}
\hline \multirow{2}{*}{$\begin{array}{c}\text { Періодичність } \\
\text { помилкових дій }\end{array}$} & \multicolumn{4}{|c|}{ Ступінь ризику помилкових дій } \\
\hline & «O» & «H» & $\langle\mathrm{C} »$ & $\langle\mathrm{K} »$ \\
\hline $0-2$ & $1-\ll \mathrm{O} »$ & $1-\ll \mathrm{H} »$ & $1-\ll \mathrm{C} »$ & $1-\langle\mathrm{K} »$ \\
\hline $3-11$ & $7-\ll \mathrm{O} »$ & $7-\ll \mathrm{H} »$ & $7-\ll \mathrm{C} »$ & $7-\ll K »$ \\
\hline $12-16$ & $14-\ll \mathrm{O} »$ & $14-\ll \mathrm{H} »$ & $14-\ll \mathrm{H} »$ & $14-\langle\mathrm{K} »$ \\
\hline Більше 16 & $17-\ll \mathrm{O} »$ & $17-\ll \mathrm{O} »$ & $17-\langle\mathrm{O} »$ & $17-\langle\mathrm{K} »$ \\
\hline
\end{tabular}

Для визначення рівня підготовленості персоналу пропонується методика, розроблена на основі теорії нечітких множин [8 - 11].

Нехай $X=\left\{x_{1}, x_{2} \ldots, x_{n}\right\}$ - безліч претендентів на навчання, а $Y=\left\{y_{1}, y_{2} \ldots, y_{p}\right\}$ - множина ознак, що характеризує стан процесу навчання.

Нехай $\quad \Phi_{R} / X * Y \rightarrow[0,1] \quad \epsilon \quad$ функцією приналежності нечіткого бінарного відношення $R$. Для всіх $x \in X$ і всіх $y \in Y$ функція $\Phi_{R}(x, y)$ - ступінь важливості ознаки $y$ за оцінкою експерта при визначенні ним відповідності процесу організації професійній підготовці. Відношення $R$ можна подати в матричній формі

$$
\left.\begin{array}{r|cccc} 
& y_{1} & y_{2} & \cdots & y_{p} \\
x_{1} & \Phi_{\mathrm{R}}\left(x_{1}, y_{1}\right) & \Phi_{\mathrm{R}}\left(x_{1}, y_{2}\right) & \cdots & \Phi_{\mathrm{R}}\left(x_{1} y_{p}\right) \\
x_{2} & \Phi_{\mathrm{R}}\left(x_{2}, y_{1}\right) & \Phi_{\mathrm{R}}\left(x_{2}, y_{2}\right) & \cdots & \Phi_{\mathrm{R}}\left(x_{2}, y_{p}\right) \\
\cdots & \cdots & \cdots & \cdots & \cdots \\
x_{n} & \Phi_{\mathrm{R}}\left(x_{n} y_{1}\right) & \Phi_{\mathrm{R}}\left(x_{n}, y_{2}\right) & \cdots & \Phi_{\mathrm{R}}\left(x_{n} y_{p}\right)
\end{array}\right)
$$

Нехай $\pi / \mathrm{Y} * \mathrm{Z} \rightarrow[0,1]$ є функцією приналежності нечіткого бінарного відношення $S$. Для всіх $y \in Y$ i всіх $z \in Z, \pi_{s}(y, x) \in$ ступенем приналежності або сумісності програм навчання $z$ з ознакою $y$ :

$$
\begin{array}{c|cccc} 
& z_{1} & z_{2} & \ldots & z_{m} \\
y_{1} & \pi_{\mathrm{s}}\left(y_{1, z_{1}}\right) & \pi_{\mathrm{s}}\left(y_{1, z_{2}}\right) & \ldots & \boldsymbol{\pi}_{\mathrm{s}}\left(y_{1, z_{m}}\right) \\
y_{2} & \boldsymbol{\pi}_{\mathrm{s}}\left(y_{2, z_{1}}\right) & \boldsymbol{\pi}_{\mathrm{s}}\left(y_{2, z_{2}}\right) & \ldots & \boldsymbol{\pi}_{\mathrm{s}}\left(y_{2, z_{m}}\right) \\
\cdots & \ldots & \ldots & \ldots & \ldots \\
y_{p} & \boldsymbol{\pi}_{\mathrm{s}}\left(y_{p, z_{1}}\right) & \boldsymbol{\pi}_{\mathrm{s}}\left(y_{p, z_{2}}\right) & \ldots & \boldsymbol{\pi}_{\mathrm{s}}\left(y_{p, z_{m}}\right)
\end{array}
$$

Елементи матриці $T$ визначаються функцією приналежності

$\mu_{A_{1}}(x, y)=\frac{\sum_{y} \Phi_{\mathrm{R}}(x, y) * \pi_{s}\left(y, z_{i}\right)}{\sum_{y} \Phi_{\mathrm{R}}(x, y)}$

для всіх $x \in X, y \in Y, z \in Z$.

Сума $\sum_{y} \Phi_{\mathrm{R}}(x, y)$ дорівнює деякій підмножині

$1 \max _{x} \min \left[\mu_{A_{1}}(x) \mu_{A_{2}}(x)\right]=\sup \mu_{A_{1}} \cap \mu_{A_{2}}(x)$ 


$$
\begin{array}{r|cccc} 
& z_{1} & z_{2} & \ldots & z_{m} \\
x_{1} & \mu_{A_{1}}^{\left(x_{1}, z_{1}\right)} & \mu_{A_{2}}\left(x_{1, z_{2}}\right) & \ldots & \mu_{A_{m}}\left(x_{1, z_{m}}\right) \\
T=x_{2} & \mu_{A_{1}}\left(x_{\left.2, z_{1}\right)}\right. & \mu_{A_{2}}\left(x_{2, z_{2}}\right) & \ldots & \mu_{A_{m}}\left(x_{\left.2, z_{m}\right)}\right) \\
\ldots & \ldots & \ldots & \ldots & \ldots \\
x_{n} & \mu_{A_{1}}\left(x_{\left.n, z_{1}\right)}\right. & \mu_{A_{2}}\left(x_{n, z_{2}}\right) & \ldots & \mu_{A_{m}}\left(x_{n, z_{m}}\right)
\end{array}
$$

Значення елементів підмножини вказують на кількість найважливіших ознак $y$, що характеризують стан навчального процесу, і можуть бути використані для порівняння рівня професійної підготовки конкретного претендента з заданими вимогами, а $\mu_{A_{1}}(x, y)$ можна інтерпретувати як зважений ступінь переваги $z_{1}$ претендентом $x$.

Функція приналежності задовольняє визначення опуклої нечіткої множини

$$
\mu_{A_{1}}\left[\lambda\left(x_{1, z_{i}}\right)+(1-\lambda)\left(x_{2,}, z_{i}\right)\right] \geq \min \left\lfloor\mu_{A_{i}}\left(x_{i, z_{i}}\right), \mu_{A_{i}}\left(x_{2,}, z_{i}\right)\right\rfloor .
$$

Оскільки всі $\mu_{A_{1}}(x, y)$ опуклі, їх перетинання також опуклі функції. Таким чином, можна побудувати матрицю $W$ :

$W=\left|\begin{array}{c}\mu_{A_{j}}\left(x_{1}, z_{1}\right) \wedge \mu_{A_{2}}\left(x_{1}, z_{2}\right) \ldots \mu_{A_{m-1}}\left(x_{1}, z_{m-1}\right) \wedge \mu_{A_{m}}\left(x_{1}, z_{m}\right) \\ \mu_{A_{j}}\left(x_{2}, z_{1}\right) \wedge \mu_{A_{2}}\left(x_{2}, z_{2}\right) \ldots \mu_{A_{m-1}}\left(x_{2}, z_{m-1}\right) \wedge \mu_{A_{m}}\left(x_{2}, z_{m}\right) \\ \ldots . \\ \mu_{A_{j}}\left(x_{n}, z_{1}\right) \wedge \mu_{A_{2}}\left(x_{n}, z_{2}\right) \ldots \mu_{A_{m-1}}\left(x_{n}, z_{m-1}\right) \wedge \mu_{A_{m}}\left(x_{n}, z_{m}\right)\end{array}\right|$

У даній моделі поріг поділу зони приналежності буде обмежений умовою

$1<\min _{i j} \max _{x} \min \left\lfloor\mu_{A 1}\left(x, y_{i}\right), \mu_{A_{j}}(x, z, j)\right\rfloor$.

Встановлення порога відмінності дозволяє перейти до визначення значень рівня професійної підготовки фахівців $M_{i}, \mathrm{i}=1,2, \ldots m$.

$$
M_{i}=\left\{x\left|\mu_{A_{i}}(x)\right| \geq \min _{i j} \max _{x} \min \left\lfloor\mu_{A_{1}}\left(x, z_{i}\right), \mu_{A_{j}}\left(x, z_{j}\right)\right\rfloor\right\}
$$

для всіх $x \in M$.

Таким чином, сутність запропонованого методу полягає у визначенні показників професійної підготовки персоналу господарства перевезень залізниці і порівнянні їх із граничними значеннями.

Моніторинг працівників господарства перевезень при роботі в нестандартних ситуаціях має велике практичне значення при забезпеченні безпеки руху поїздів, тому підвищення їхнього професійного рівня $\epsilon$ суттєвим завданням. Це дозволить тримати оперативне управління системою в постійному тонусі з високим рівнем безпеки.

Розглянемо спрощену процедуру визначення рівня оперативної підготовки працівників господарства перевезень при діях у нестандартних ситуаціях на прикладі операторів сортувальної гірки:

- на станції розробляються тестові питання 3 безпеки руху на сортувальній гірці. Питання повинні стосуватись тільки роботи оператора в нестандартних ситуаціях (ліквідація аварійних ситуацій, пожеж та ін.). Не повинно бути інших питань, які відволікають розум працівника від безпосередньої його роботи (номер якоїсь телеграми, наказу та ін.);

- перед прийманням чергування операторам гірки надається бланк 3 п'ятьма питаннями. На ці питання оператор повинен відповісти протягом однієї хвилини. Відповідь оцінюється за п'ятибальною шкалою залежно від кількості правильних відповідей (1 правильна відповідь - 1, 5 правильних відповідей 5 і т.д.). Результати записують у журнал цільового інструктажу і тієї ж доби заносяться до комп'ютера для автоматичної обробки результатів;

- після тестування необхідно обов'язково сказати працівнику правильні відповіді. За неправильні відповіді працівника в жодному разі не треба притягувати до дисциплінарної відповідальності. Ці результати необхідно враховувати при складанні тематики щодо проведення технічних занять.

У процесі даного заходу перевіряється правильність дій операторів гірки в нестандартних ситуаціях, яка буде оцінюватися рівнем підготовки операторів гірки при діях у нестандартних ситуаціях:

$R_{\text {ПО }}=\frac{\sum_{i=1}^{n} R_{\text {ПО }}}{n}$,

де $R_{П O_{i}}$ - результат перевірки і-го оператора;

$n$ - кількість операторів, яких було перевірено за певний період часу.

Для окремо обраної сортувальної станції було проаналізовано експертні дані, результати технічного навчання та результати перевірок персоналу з безпеки руху, визначено рівень підготовки операторів гірки при діях у нестандартних ситуаціях до та після впровадження заходів 3 удосконалення процедури їх оперативного контролю (табл. 4). 
Таблиця 4

Результати визначення рівня підготовки операторів гірки при діях у нестандартних ситуаціях

\begin{tabular}{|c|c|c|c|}
\hline \multirow{2}{*}{ Група } & \multirow{2}{*}{ Кількість працівників у групі } & \multicolumn{2}{|c|}{ Сумарна кількість балів } \\
\cline { 3 - 4 } & & до впровадження заходів & після впровадження заходів \\
\hline 1 & 6 & 22 & 32 \\
\hline 2 & 6 & 23 & 28 \\
\hline 3 & 6 & 22 & 30 \\
\hline 4 & 6 & 21 & 25 \\
\hline 5 & 6 & 21 & 26 \\
\hline 6 & 6 & 19 & 32 \\
\hline 7 & 6 & 23 & 30 \\
\hline 8 & 6 & 21 & 28 \\
\hline 9 & 6 & 20 & 26 \\
\hline 10 & 6 & 216 & 282 \\
\hline Разом & 60 & 3,60 & 4,70 \\
\hline \multicolumn{2}{|l|}{ Рівень підготовки (оцінка) } & & \\
\hline
\end{tabular}

3 табл. 4 видно, що після впровадження заходів 3 удосконалення процедури їх оперативного контролю рівень підготовки операторів гірки в нестандартних ситуаціях прогнозовано буде підвищеним в 1,3 разу.

\section{Висновки 3 дослідження і перспективи, подальший розвиток у даному напрямку}

Професійна підготовка персоналу господарства перевезень залізничного транспорту має велике значення в проведенні профілактичної роботи 3 забезпечення безпеки руху поїздів.

В основі технології моніторингу цього рівня закладено математичний апарат теорії нечітких множин. Сутність запропонованого методу полягає у визначенні показників професійної підготовки персоналу господарства перевезень залізниці і порівнянні їх із граничними значеннями.

Даний підхід можна застосовувати при моніторингу рівня підготовки персоналу будь-яких господарств залізниць.

\section{Список використаних джерел}

1. Common Safety Method for risk evaluation and assessment Guidance on the application of Commission Regulation (EU) 402/2013 [Електронний ресурс] // Office of Reil Regulation. 2015. - Режим доступу: http://orr.gov.uk/_data/assets/pdf_file/0006/3867/co mmon_safety_method_guidance.pdf.

2. Розсоха, О.В. Аналіз функціонування системи управління безпекою руху поїздів на залізницях України [Текст] / О.В. Розсоха, М.В. Люлін, О.В. Щербина // Залізничний транспорт України. 2013. - № 5/6. - C. 21-25.

3. Розсоха, О.В. Аналіз функціонування систем управління безпекою руху поїздів на залізницях країн Євросоюзу [Текст] / О.В. Розсоха,
Ю.В. Смачило // Зб. наук. праць Укр. держ. акад. залізнич. трансп. - Харків: УкрДАЗТ, 2015. Вип. 151. - С. 4-11.

4. Розсоха, А. В. Функционирование систем управления безопасностью движения на железных дорогах Украины и России [Текст] / А.Н. Огарь, Ю.О. Пазойский, А.В. Розсоха [и др.] // Зб. наук. праць Укр. держ. ун-ту залізнич. трансп. - Харків: УкрДУЗТ, 2015. - Вип. 156. - С. 18-28.

5. Redmill, F. Human Factors in Safety-Critical Systems [Text] / F. Redmill, J. Rajan (eds.) // ButterworthHeinemann, Oxford, 1997. - 300 p.

6. Rasmussen, J. Cognitive Engineering: Concepts and Applications [Text] / J. Rasmussen, A.-M. Pederesen, L. Goodstein. - Wiley, New York, 1995. - 250 p.

7. Vincenzo Torretta. Decision support systems for assessing risks involved in transporting hazardous materials: A review [Text] / Vincenzo Torretta, Elena Cristina Rada, Marco Schiavon, Paolo Viotti // Safety Science, Vol. 92, February 2017. - P. 1-9.

8. Chaolong Jia. Study of Management Information System of Railway Permanent Way Safety Risks and Comprehensive Evaluation [Text] / Chaolong Jia, Weixiang $\mathrm{Xu}$, Hanning Wang // Procedia Engineering, 2011. - Vol. 15. - P. 1293-1297.

9. Яхъяева, Г.Э. Нечеткие множества и нейронные сети [Текст] / Г.Э. Яхъяева. - М.: ИнтернетУниверситет Информационных Технологий; Бином. Лаборатория знаний, 2006. - 316 с. Сер. Основы информационных технологий.

10. Тэрано, Т. Прикладные нечеткие системы [Текст] / Т. Тэрано, К. Асаи, М. Сугэно. - М. : Мир, 1993. $368 \mathrm{c.}$

11. Кохман, А. Введение теории нечетких множеств в управлении предприятием [Текст] / А. Кофман, Х. Хил. Алуха. - М.: Высшая школа, 1992. - 223 с. 


\begin{abstract}
A. В. Розсоха,
Технология

И. В. Берестов, мониторинга

А. В. Шаповал. уровня профессиональной подготовки персонала хозяйства перевозок железнодорожного транспорта. Уровень профессиональной подготовки персонала хозяйства перевозок железнодорожного транспорта имеет большое значение в проведении профилактической работы по обеспечению безопасности движения поездов.
\end{abstract}

В статье предложен метод определения уровня профессиональной подготовки персонала. Этот метод заключается в определении показателей профессиональной пригодности персонала и сравнении их с предельными значениями. В основу математического аппарата метода положена теория нечетких множеств.

В статье также предложена упрощенная процедура определения уровня оперативной подготовки работников хозяйства перевозок при действиях в нестандартных ситуациях на примере операторов сортировочной горки.

Ключевые слова: уровень профессиональной подготовки, обучение персонала, безопасность движения поездов, железнодорожный транспорт.

O. Rozsokha, I. Berestov, A. Shapoval. Monitoring technology of the level of staff training transportation service of railway transport. An important direction in implementing measures to improve the safety of traffic is preventive work, which has many aspects, but has one goal: to completely eliminate or minimize security breaches in train and shunting operations, as well as traumatic events. The level of professional training of railway transport personnel is of great importance in carrying out preventive work to ensure the safety of train traffic.

The purpose of these studies is to identify ways to improve the quality of the transportation process while improving the safety management system of train traffic. One of the relevant measures is the development of a technology for monitoring the level of professional training of railway transport personnel.

Under the continuous monitoring of the safety of train traffic, active control over the activities of the railway industry by the competent regulatory authorities should be understood in order to fulfill the safety requirements.

The article suggests a method for determining the level of professional suitability of personnel. This method consists in determining the indicators of the professional suitability of personnel and comparing them with the limiting values. The theory of fuzzy sets is based on the mathematical apparatus of the method.

The article also proposes a simplified procedure for determining the level of operational training of transport workers in actions in non-standard situations using the example of sorting roller operators.

Practically such an approach to assessing the level of professionalism and preparedness of personnel can be used in training centers in the process of checking the level of theoretical knowledge, in training centers when assessing practical skills using technical training facilities.

Key words: level of professional training, staff training, train safety, railway transport.

Надійшла 26.04.2017p.

Розсоха Олександр Володимирович, кандидат технічних наук, дочент кафедри залізничних станцій та вузлів, Украӥнський державний університет залізничного транспорту, Харків, Україна. E-mail: s4749@ukr.net.

Берестов Ігор Вячеславович, кандидат технічних наук, доцент кафедри залізничних станцій та вузлів, Украӥнський державний університет залізничного транспорту, Харків, Україна. E-mail: i.berestov@mail.ru.

Шаповал Ганна Василівна, кандидат технічних наук, дочент кафедри залізничних станцій та вузлів, Украӥнський державний університет залізничного транспорту, Харків, Україна. E-mail: ann.shapoval@ukr.net.

Rozsokha Olexandr, Associate Professor, Doctor of Science (Ph.D.), Ukraine State University of Railway Transport, Kharkiv, Ukraine. E-mail: s4749@ukr.net.

Berestov Igor, Associate Professor, Doctor of Science (Ph.D.), Ukraine State University of Railway Transport, Kharkiv, Ukraine. E-mail: i.berestov@mail.ru.

Shapoval Ganna, Associate Professor, Doctor of Science (Ph.D.), Ukraine State University of Railway Transport, Kharkiv, Ukraine. E-mail: ann.shapoval@ukr.net. 